\title{
The Formation of Italian-American Diasporic Space: An Account of the Emergence of An Italian-American Community in Philadelphia
}

\author{
Hechen $\operatorname{Liu}^{1, \mathrm{a}}$ \\ College of Arts and Sciences, Washington University in St. Louis, St. Louis, MO, 63105, USA \\ "Corresponding author. Email: angela@cas-harbour.org
}

\begin{abstract}
In this paper, the author seeks to outline and theorize the emergence and formation of a diasporic Italian American identity. The researcher focuses on historical concerns as well as contemporary dynamics but is principally interested in the creation of an identity that is sustained even today while being internally diverse and continually subject to change. The author will illustrate this, concerning the Italian-American community in Philadelphia. The paper will be concluded with how a diasporic space is formed and how it mutually interacts with the formation of a diasporic identity. Moreover, the paper will explain how the process of formation of collective identification, or nationality, is imagined and re-imagined in an Italian-American community in South Philadelphia.
\end{abstract}

Keywords: Diasporic space, Imagined community, Nationality, Italian-American community, South Philadelphia

\section{INTRODUCTION}

As the reference to a real or imagined homeland suggest, we need to grasp that the Italian presence in the US is not just about continuity with what came before, but also about how communities change (and can change radically) while retaining a common self-belief in the points of origin. In order to understand this, the paper will bring ideas from the social and human sciences, including those of diasporic space and imagined communities. Before this, the paper will offer a modern historical background to the Italian American story, after which it tries to explore the meaning of how this presence is imagined and re-imagined by Italian Americans today. Specifically, the paper will focus on South Philadelphia, where the second-largest Italian American community in the United States is located, and then conclude by analyzing how a diasporic identity is formed and developed through the lens of this Italian community in Philadelphia.

\section{ANALYSIS}

\subsection{Italian American Diasporas}

Before the arrival of farmers and laborers from southern Italy, the immigration pattern of Italians was usually individuals traveling, so there are few sizable records of large numbers of Italian populations in America until the 1880 s [6]. It was around this time that the era of mass immigration from Italy to Philadelphia (and elsewhere) corresponded with a significant change in the regional origin of the newcomers of Italian background. The early immigration before the 1880 s was commonly comprised of people from northern Italy, especially places like Liguria and Piedmont [8]. Later, as records show, the northerners were increasingly accompanied by greater numbers of southerners migrating to the United States [6]. The degree of Italian immigration varied from province to province, yet all of southern Italy suffered equally during this period from high taxes, exhaustion of the land, a decline in the lemon market, and a grapevine disease, accompanied by a rise in population [2]. As a consequence, and in a relatively short time, the immigrants from southern Italy outnumbered northerners and became the main contribution to the population of Italian workers. Specifically, in Philadelphia, their population increased from 10,023 by 1890 to 76,734 in 1910, which can be seen as table below [6].

Table 1. Demographic Statistics of Italians in Philadelphia from 1880-1910

\begin{tabular}{|l|l|l|l|l|}
\hline Year & 1880 & 1890 & 1900 & 1910 \\
\hline Population & 1656 & 10023 & 46648 & 76734 \\
& & & & \\
\hline
\end{tabular}

The pattern of Italian migrant settlement from the 18th to early 19th century was characterized by particular groups of professions, such as musicians, play-writers, artisans, traders, and religious figures [2]. From the perspective of Italians at that time, the United States was a symbol of independence and self-government [8]. Philadelphia was especially appealing to Italian traders, for they could 
connect it with Italian port cities, such as Genoa. The instability of political and economic atmosphere led to the migration of upper-class elites, who were mostly interest-driven, thus enabled the creation of multiple transnational trading routes from Philadelphia to Italy [8].

This pattern changed dramatically. However, after the Kingdom of Italy declared its independence from foreign controls in 1861. With stability at home, fewer traders, political figures, and artisans chose to leave. In contrast, farmers and laborers seeking better economic conditions did, mainly due to poor agricultural conditions and opportunities for labor [2]. The principal reasons for this movement were pushing factors, with these new arrivals fleeing from poverty and economic downturn in Italy. The stories of these first waves of lower-class immigrants not only record their process of thriving but also genuinely reflect how they became, imagined and re-imagined being 'Italian', coming as they did from very different towns and regions in Italy.

The migration pattern of lower-class immigrants from the southern Italian peninsula is an important but fundamentally under-recognized observation both in the historical literature and in the social sciences as well as humanities. Specifically, neither historians nor social scientists have applied the ideas of diasporic space to an understanding of the earlier Italian community formation, including in places such as Philadelphia that will be next discussed

\subsection{Italian Community in Philadelphia}

When the Italian immigrants started to move to the United States in the late 19th century, immigrants of different regional backgrounds found it difficult to perceive themselves as members of the same national group. Indeed, the grouping behaviors of these Italian immigrants in Philadelphia revealed that the basic structure of their society was, more importantly, based on township instead of nationality. The Italian-American settlements in Philadelphia offer clear evidence that separated as they were by disparate dialects and traditions, individuals from different regions and villages shied away from one another. As a result of this geographical and ideological difference among Italian immigrants, their neighborhoods in Philadelphia developed as a series of single communities [6].

Indeed, the perception of the township was essential, for it helped Italian immigrants to define their identities. Township also meant trust and fellowship in many cases. For example, the Angelucci family imported raw materials from their hometown into Philadelphia for other immigrants in the neighborhood. They had specified and ordered the exact goods that they were looking for from Italy, and food cooked by using these authentic raw materials usually gave them a feeling of a connected township [6].

Aside from allowing one to access institutions that generally people from other communities could not access, the neighborhoods usually had strict requirements that only immigrants coming from the same town in Italy as they did could enter the community and live there. The opposite of the perception of collective identity was the rejection of other ethnic identities. The diversified identities of Italian immigrants might have enabled the recognition of a single ethnicity when they came up to the stage right before the World War II[7].

As mentioned before, the immigrants to the United States usually came from southern rural regions in Italy. They typically departed from their hometowns, such as Abruzzi, Campania, and Sicily, and they arrived in Northeastern cities, such as New York, Boston, and Philadelphia. The Italian population was increasing rapidly and had taken a huge part of the labor market. For example, in 1895, almost half million Italians were living in the United States, with 100,000 of them resided in New York City [1], and it was estimated that $90 \%$ of the public works employees in the city were Italians. From 1880 to 1915,4 million Italians migrated to the United States, and 3 million of them arrived between 1900 and 1914 [5]. The low-skilled peasant farmers had professions such as railroad and construction workers and factory laborers. Those occupations usually demanded their workers to do simplistic and repetitive works.

These earliest diasporic groups of people, who retained a strong desire for a return to their hometown, worked as low-payment laborers in order to earn money quickly and send remittances back home to support their remaining family in Italy [6]. The working conditions and treatment of these Italian immigrants were not very favorable in the early years, and they were concentrated in the construction industry, where many worked as low-skilled laborers and were paid very little. Before coming to the United States, many of them were farmers, though they did not own lands for agricultural production.

\subsection{South Philadelphia}

South Philadelphia, which used to be a "satellite town" [11], experienced rapid growth in population and expansion in urban scale during the mid-19th century when the achievements, such as machines for mass production, of Industrial Revolution were transported to the United States and were enjoyed significantly by American cities. The influx of working-class laborers and immigrants seeking jobs contributed the most to the population of South Philadelphia. Before the Italians arrived in the $1880 \mathrm{~s}$, the area accepted and held a large amount of impoverished Irish refugees during the Great Irish Hunger [3]. Eventually in 1854, the ever-expanding, industrializing, and urbanizing South Philadelphia became a part of the City of Philadelphia according to the Act of Consolidation.

The continuing influx of immigrants, including the Irish, the Jewish and Italian groups, turned the once satellite town into a sub-center of the City of Philadelphia. The earliest waves of southern Italians, who worked as factory laborers and construction workers, generally had a "sojourner mentality" [6]. They considered themselves as 
non-permanent residents and that they eventually would go back to their hometowns. Many of them constantly traveled between southern Italy and South Philadelphia. What is more, they identified and claimed themselves not as Italians but according to the rural regions where they came from. As these communities developed and thrived in South Philadelphia, experiencing anti-Italian sentiment, the weakening role of local media which was used to release news from hometowns and later became entirely English-oriented, and the increasing cooperation among regional associations, the sub-national divisions transitioned to the unification of Italian groups.

No matter how times have changed, either the earlier waves of impoverished Italian immigrants or their offspring, who mainly spoke English and considered themselves as Italian-Americans, the everlasting factor which led to the unification of Italian communities in South Philadelphia was an anti-Italian sentiment or anti-Italianism. Elements of organized crime, competition for jobs and housing, and religions of Italian immigrants contributed to the widespread anti-Italian sentiment among other immigrant groups. This sentiment strengthened the connections among Italian communities in South Philadelphia and united Italian Americans.

After the First World War, Americans urged to restrict the influx of immigrant groups from Europe through the law. As a result, Congress passed the Emergency Quota Act restrict especially the influx of Jews and the immigrant groups that were not welcomed by Americans [4]. It was at this point that the Italian immigrants no longer considered themselves as "birds of the passage," or non-permanent lodgers since they knew that they would have to reside in the United States forever or else they, or their families, would not be able to return to America easily.

First of all, the determination for permanent residence initiated more local associations and even gangs. Sometimes, the local association had a connection with gangsters and conducted illegal business. For example, the bootlegging of liquor smuggling in South Philadelphia in the 1920s and 1930s was controlled mostly by the Lanzetta Brothers, which was a group that ran an illegal business in Philadelphia [12]. Most of the gangsters in the 1920s were born in the Little Italy of South Philadelphia and were children of the earlier waves of Italian immigrant workers in the later 19th century. Around the 1930s, the Philadelphia Daily News depicted Little Italy as a dangerous place of "the kings of the underworld." Even though other ethnic groups were practicing illegal activities simultaneously and Italian American gangsters had approximately the same crime rates as the other groups did, the Italian Americans were considered the most dangerous and notorious.

Around the 1900 the arrival of more than a million Italian immigrants, who had never experienced formal education and were extremely hard-working and industrious, competed for low-payment and low-skilled works with other earlier immigrant ethnic groups in the labor market of South Philadelphia; the intense competition also existed in the housing market [9], not least amongst Irish, Polish, and Russian-Jew communities.
In addition to social and economic factors, religion was a common factor that led to conflict between Italian immigrants and other ethnic groups. Religious believers in the United States inherited the Protestant belief and traditions from their European ancestry. However, the Protestants were constantly in conflict and competition with the Catholics. As a result of this religious conflict and competition, and supplemented by the fact that most of the Italians were Catholics, the anti-Italianism aligned with anti-Catholic sentiment. The activities resulting from anti-Catholic sentiment in the earlier ages included religious persecution and destruction of religious sites. Later in the 1920s, especially in New Jersey and Philadelphia, where one of the largest Italian-American population was located, the Ku Klux Klan (KKK) ignited a wave of anti-Catholic sentiment in order to preserve their Protestant traditions, nativist sentiment, and supremacy. What is more, the engrained anti-Catholicism intensified the sentiment to a greater extent. Resulting from the widespread sentiment, the sub-national divisions among the Italian American community became weaker, and an overarching identity of "Italianhood" was created [6].

Aside from anti-Italian sentiment, the media also helped to generate the nationality of Italy among Italian-American communities. Italian diaspora newspapers were a way to spread ideology and political opinions. What is more, it ensured that its readers receive the same information day by day, and members of such newspapers would essentially become part of the unification of the same ideology. The readers' consumer behaviors, such as what newspapers they tended to order, were a reflection of their identity. For example, in the 1930s, L'Opinione, in South Philadelphia, spread the idea to Italian-American communities that "only getting together can soldiers be strong, fight, and protect themselves" [13]. It also encouraged Italian Americans to stand against anti-Italian sentiment and ethnic discrimination [13]. This propagandization against anti-Italianism invited Italian Americans to embrace the idea of an Italian nationality has the basis for collective consciousness, which they depended as a means to identify themselves. The transformation of local radio stations also contributed to the formation of Italian nationality. Initially, the radio station of each Italian immigrant community was created and organized voluntarily in a non-profit way. The main purpose of such numerous local radio stations was to keep Italian immigrant groups in touch with their hometowns [6]. Usually, the channels were in Italian and would play Italian music. What is more, each radio station represented the hometown of an immigrant group. Before the Great Depression and the high commercialization of broadcasting system in the 1930 s, radio stations strengthened sub-national divisions for they ensured the connection between Italian immigrants and their hometowns, and thus the broadcasting system enabled people to stick with their ethnic identities, or sub-nationality, such as Abruzzi, Sicily, and Calamaria. However, the commercialization of the broadcasting system transformed many local Italian-speaking radio stations into commercially-oriented English-speaking radio 
stations [7]. This reduced sub-national divisions and encouraged localized Italian audiences to become common American listeners of a general broadcasting system. The weakening of sub-national identities facilitated a new generation of an overarching diaspora Italian nationality, which Italian Americans could rely on to identify themselves.

The efforts of preserving sub-national ethnic identities through associations were found commonly in Italian immigrant communities in South Philadelphia, but later the disparate associations gathered up to create a much powerful unification, contributing to the nationality.

The final stage that contributed to the transition from sub-national divisions to an overarching nationality was national pride. After migrating to the United States for employment and being separated from their hometowns for decades, Italian Americans finally saw Italy on global news. When Mussolini practiced aggressive foreign policies, Italian Americans, for the very first time, saw in Italy in a global society. In the 1930s and 1940s, Italian Americans already started to consider themselves not as Italians but as people having Italian ancestry; however, the national pride would even affect their decisions for the presidential elections. In 1940, the Philadelphia Italian origin voters, who supported Roosevelt, dropped to $53 \%$ as compared to $65 \%$ in 1936 because Roosevelt opposed Italy's attack on France in June of that year [6].

\section{DISCUSSION}

The experience of Italian-American community in South Philadelphia shows that diaspora is a process that contains the displaced group members' practices of collective social, cultural and religious identification, and that the formation of a diasporic space requires hybridity of different sub-national identities, which, in the case of Italian-American community, is the differentiation in terms of hometown regions. Usually, diaspora is referred to the transnational displacement of a group of people from their homeland, and that definition does not necessarily mean that the diasporic group needs to have a desire for return. In the case of Philadelphia Italian Americans, at the very beginning, when they first arrived, the United States was nothing but a non-permanent lodging place that provided them with short-term employment and low-paying housing.

However, after the Quota Act was proposed and restriction was set upon immigrants to the United States, this country suddenly became their permanent residence, and the change of policy greatly impacted the ways they lived and worked as compared to the earlier stages. These Italian-American communities developed provincial associations so that they could depend on each other and benefit from mutual-aid [6]. As they were trying to own housing and thrive in this country, they had to compete with other immigrant groups for job opportunities and cheap housing. As a result, they received anti-Italian sentiment and hatred from other immigrant ethnic groups [10].
Of course, the process of trying to establish permanent Italian residence in the United States progressed along with the mutual effect of Anti-Italianism and the unification of Italian immigrants. The anti-Italian sentiment toward Italian workers in the labor and housing market and the earlier American residents' worry of Italians' threaten to their safety initiated the collectivization of even more Italians. Gradually as they lived stably, they organized local radio stations and newspaper to keep their fellows in connection with hometown. The purpose of these media was to share information of Italy to the immigrants, especially they no longer had the desire for return and already owned stabilized occupations in the United States. The media eventually ensured that they shared the same information and accepted the same ideology of nationality. In this process, the borders between sub-national divisions were eliminated, and an overarching nationality was generated, which held Italian Americans together to voice for their political rights and opinions.

\section{Conclusion}

In conclusion, according to Demetriou's theory of diaspora formation, the Italian Americans, within the context of a displaced space, addressing the collective interest of members of the social collectivity, which sustained a collective national, cultural, and religious identity, and thus their offspring, who grew up in such diasporic place, not simply considered themselves as either Americans or Italians but as Italian-Americans. Therefore, further studies are needed especially when we discuss about such cases.

\section{ACKNOWLEDGMENT}

First and foremost, I would like to show my deepest gratitude to my professor from The University of Edinburgh, who has provided me with valuable guidance in every stage of the writing of this thesis. Further, I would like to thank all my friends and roommates for their encouragement and support. Without all their enlightening instruction and impressive kindness, I could not have completed my thesis.

\section{REFERENCES}

[1] Cribbs, B. (2014). Immigrants From Italy-Article From 1895. Retrieved from http://www.genealogybuff. com/.ny/ny-italian-immigrants.html.

[2] Dickinson, J. Y. (1966). Aspects of Italian Immigration to Philadelphia. The Pennsylvania Magazine of History and Biography, Vol. 90, No. 4 (Oct., 1966), pp. 445-465. 
[3] Foster, R.F (1988). Modern Ireland 1600-1972. Penguin Group.

[4] Higham, J. (1963). Strangers in the Land. Rutgers University Press.

[5] Lorrizo, L. J. (1980). Italian Immigration and the Impact of the Padrone System. pp. 160-162.

[6] Luconi, S. (1996). The Changing Meaning of Ethnic Identity among Italian Americans in Philadelphia during the Inter-war Years. Pennsylvania History: A Journal of Mid-Atlantic Studies, Vol. 63, No. 4 (Autumn 1996), pp. 561-578.

[7] Luconi, S. (2002). Radio Broadcasting, Consumer Culture, and Ethnic Identity among Italian Americans in the Interwar Years. Italian Americana, Vol. 20, No. 2 (Summer 2002), pp. 150-159.

[8] Luconi, S. (2017). Italians and Italy. Retrieved from https://philadelphiaencyclopedia.org/ archive/italians-and-italy/.

[9] Mangione, J. and Morreale B. (1991). La Storia: Five Centuries of the Italian American Experience. New York: Harper-Collins.

[10] Mullan, M. L. (2012). The Civic Life of Abruzzo Transferred to Philadelphia: The Italian-American Voluntary Association, 1890-1924. Italian Americana, Vol. 30, No. 1 (Winter 2012), pp. 5-21.

[11] Paxon, H. D. (1926). Where Pennsylvanis History Began. The Swedish Colonial Society.

[12] VJ (2010). Mickey Duffy and the Lanzetta Brothers. Retrieved

from https://fikklefame.com/mickey-duffy-and-the-lanzetta-brot hers/.

[13] Saracco, F. (1934). Unpublished journals, pp. 19, in Francesco Saracco Papers, BIES: L'Opinione, Feb. 15, 17, 1934. 